\title{
NORMATIWITEIT VERSUS NEUTRALITEIT IN DIE TEGNIESE WETENSKAPPE
}

\section{Inleidende gedagtes}

Die essens van hierdie referaat is nie 'n pleidooi vir 'n normatiewe benadering tot beoefening van die wetenskap op natuurkundige terrein nie, maar eerder 'n aanvaarding van die onvermydelikheid daarvan en 'n poging om dan die konsekwensies in oënskou te neem.

As ons 'n globale blik oor die hele tegniese wetenskap en sy historiese ontwikkeling neem, dan is dit duidelik dat dit nie hier net gaan oor die hoe van dinge nie, $\mathrm{d}$ w s die inhoud en werkinge van 'n bepaalde verskynsel nie, maar wel oor die vanwaar, die hoe en die waarnatoe. Die genoemde drie komponente is altyd teenwoordig maar is nie altyd ewe sterk beklemtoon nie. Aangesien die lewens- en wêreldbeskouing van die ondersoeker veral ter sprake kom by die eerste en laaste komponent, is voorstanders van die neutraliteitsgedagte dadelik geneig om te sê dat dit in die natuurwetenskap net om die hoe gaan en waar laasgenoemde moontlik wel deur subjektiewe norme geaffekteer word, moet die geaffekteerde deel ook afgetrek word en slegs die oorblyfsel kwalifiseer dan as ware wetenskap. Nou, as mens bereid is om die wetenskapsbegrip tot só 'n mate te reduseer, dan kan wat oorbly seker met enige standpunt versoen word, maar daardeur word niks konstruktief bereik nie.

Vanaf die Grieke tot aan die begin van die 17e eeu het die hoofklem geval op die vanwaar en waarom van dinge. Met Galileo se inleiding van die eksperimentele metode het daar in die volgende drie-en-'n-half eeue 'n verskuiwing na die hoe oorgegaan en in die afgelope aantal jare 'n dramatiese swaai na die waarnatoe.

Enkele opmerkings oor die neutraliteitsgedagte. Vir 'n wetenskaplike om in homself volkome objektief te staan teenoor dit wat hy ondersoek, vereis 'n soort eerlikheid in absolute sin wat nie rekening hou met beperkinge van die mens nie. Die sondeprobleem met al sy ramifikasies is steeds in ons midde. 
Die sterk oortuigings wat vele wetenskaplikes huldig ten gunste van die neutraliteitsgedagte, het verskeie oorsake. Ons noem twee van die belangrikstes. La Place - die beroemde wiskundige van die $17 \mathrm{e}$ eeu - het die siening gehuldig dat as ons al die deeltjies van 'n sisteem se koördinate sou ken op 'n gegewe oomblik sowel as al die betrokke interaksiekragte, dan kan ons in beginsel die gedrag van die sisteem volkome beskryf in terme van die natuurwette en is ons bevindings geheel en al onafhanklik van die wetenskaplike self. Om nou die subjektiewe vooroordele van die wetenskaplike se rol te erken, sou beteken dat hier moontlik sprake is van 'n minderwaardige wetenskap teenoor die ideale wetenskapsbeeld van La Place. Selfs die reële indeterminisme wat voortgevloei het uit Heisenberg se onsekerheidsrelasie, kan die sielkundigé wortels van die La Place-siening by menige mense nie losskud nie. Die tweede en veel meer praktiese rede is dat daar uiteraard min wetenskaplikes van so groot formaat is dat hulle daadwerklik met die grense van hulle vakgebied te doen kry. Die meeste is besig om daardie enkele - maar moontlike belangrike - bakstene in die kennismuur in te bou waarvan die fondament en oriëntasie reeds vasgelê is deur die groot geeste. Hulle beoordeel die vraagstuk vanuit hulle eie navorsingservaring, is streng gemoeid met die hoe van 'n fenomeen en vanweë die afhanklike verbintenis met die kennis wat reeds vasgelê is, speel hul eie norme geen noemenswaardige rol in hul bedrywighede nie en daarom kan hulle nie insien waarom daar soveel gepraat en gewerskaf moet word rondom subjektiewe vooroordele in die wetenskap nie.

\section{'n Historiese blik}

As ons na enkele groot figure van die afgelope paar eeue kyk, dan word dit keer op keer gemerk hoedat die persoonlike lewens- en wêreldbeskouing van die navorser sy wetenskaplike arbeid beïnvloed het, maw dit was nie normvry nie. René Descartes was 'n wiskundige van die $17 \mathrm{e}$ eeu wat die analitiese meetkunde tot stand gebring het. Hy het 'n wiskundige wêreldbeeld daarop na gehou en was oortuig dat hy geroepe was (en dit veral ná 'n droom op 10 November 1618) om 'n wetenskap van die ganse natuur, gegrond op die meetkunde, te ontwerp. Hoewel hy groot sukses in die wis- 
kunde self behaal het, spreek dit vanself dat sy fisika sou faal, want selfs die materie was vir hom bloot 'n funksie van die ruimte.

'n Tweede figuur uit dieselfde tydperk was die geniale Gottfried Leibniz. Sy basies metafisiese kontinuïteitsprinsipe het onder andere uitgekristalliseer in sy daarstelling van die differensiaal- en integraalrekening. En dan kom ons by die reus onder die reuse, Isaac Newton. Dit is allerweë bekend dat hy hom sterk bemoei het met teologiese vraagstukke in sy laaste jare, maar minder bekend dat Newton se onwrikbare geloof in 'n Skepper wat 'n stabiele planetêre stelsel geskape het, 'n deurlopende effek op sy kosmologiese denke gehad het.

As ons na 'n moderne reus soos Albert Einstein kyk, dan is dit interessant om daarop te let dat sy denke oor tyd, en veral gelyktydigheid van gebeurtenisse (wat aanleiding gegee het tot die spesiale relatiwiteitsteorie), aanvanklik gestimuleer is deur sy belangstelling in filosofie, veral van Hume en Mach. Dit is bekend dat hy tot sy dood nooit die basiese postulate van die kwantummeganika wou aanvaar nie. Die indeterminisme wat voortvloei uit Heisenberg se onsekerheidsrelasie het nie gestrook met Einstein se wêreldbeeld waarin die wette van die natuur uiteindelik kousaal moes regeer nie. Hy het geglo dat die fisiese werklikheid 'n vierdimensionele ruimtetydkontinuüm is waarin gebeurtenisse reeds vooraf vasgelê is. Die verloop van tyd raak die menslike bewussyn slegs soos die gebeure hom afspeel. Dis interessant om te weet dat 'n vername teoretikus soos Bohm vandag torring aan die grondslae van die kwantummeganika, ondanks dié vak se fenomenale suksesse in die afgelope vyf dekades. In hoe 'n mate Einstein se vooroordele vir Bohm tot inspirasie dien, sal die tyd moontlik nog openbaar.

Werner Heisenberg skryf in die voorwoord van sy boek Physics and Beyond:

„Human philosophical or political problems will crop up time and time again and the author hopes to show that science is quite inseparable from these more general questions."

Die res van die boek is deurspek met die invloed van lewensbeskoulike norme op wetenskapsbeoefening. Ruth 
Anshen skryf in die slothoofstuk:

„For underlying the new ideas, including those of modern physics, is a unifying order but it is not casuality; it is purpose and not the purpose of the universe and of man but the purpose in the universe and in man."

Paczynski van die Instituut vir Sterrekunde in Warschau het onlangs in 'n artikel aangedui hoedat die Copernikaanse revolusie 'n dogma in moderne wetenskaplike denke geword het. Die gang van denke het kortliks as volg verloop: Copernicus het die aarde onttroon as die unieke middelpunt van die heelal. Dit was maar net nog 'n planeet om die son. Die son is daarna gerelegeer tot net nog 'n ster in 'n melkwegstelsel wat ook maar een van duisende stelsels is. Hieruit het die universele kosmologiese beginsel voortgevloei dat die heelal orals dieselfde is en dan ook te alle tye dieselfde sal wees. Dit het aanleiding gegee tot die teorie van 'n kosmos in statiese toestand. Die getuienis van die radiosterrekunde dat daar wel verandering met die tyd was, kon dan beteken dat die heelal een groot ossilerende sisteem is en tog tyd afhanklik is, maar as gevo'g van die feit dat ons in een van die oneindige aantal ossilasies is en nie in 'n unieke ossilasie nie. Die moderne mens wil nie aanvaar dat net die aarde mense op het nie - nie as gevolg van enige wetenskaplike bewyse nie - maar as eindelike gevolg van die feit dat hierdie planeet nie ' $n$ unieke sentrale posisie in die heelal besit nie. Paczynski sluit af: "Copernicus was most efficient in removing us from any kind of centre".

In 'n oorsig van 'n boek wat geskryf is deur die lede van die Science Policy Research Unit van Sussex Universiteit wat handel oor toekomsmodelle in die heelal met spesiale verwysing na die boek Limits to Growth, merk Challis op: „There is a theme which runs through the book, namely that the dedicated and able individual may strive after neutrality but in the assumptions he makes for modelling purposes, his own subjective values and goals will inevitable shine through".

In 'n referaat van hierdie aard is dit nodig om kennis te maak met die denke van Michael Polanyi van Oxford. Hy was aanvanklik 'n fisiese skeikundige wat hom later tot die filosofie gewend het. Sy uitgangspunt is: Wetenskaplikes weet meer as wat hulle kan meedeel. Daar is 'n ongeopenbaarde 
kennisfaktor teenwoordig wat die wetenskaplike se werk beinvloed en derhalwe is die mikpunt van algehele objektiwiteit 'n gevaarlike illusie, dws gevaarlik vir die wetenskap self. Ons noem enkele resultate voortvloeiend uit Polanyi se denksisteem:

* Aangesien die La Place-siening (waarna vroeër in hierdie referaat verwys is) onrealiseerbaar is, moet dit nie ' $n$ serieuse rol in ons wetenskapsbedryf speel nie. Die La Place-dwaling lei tot 'n oorbeklemtoning van waarnemingsakkuraatheid ten koste van 'n oordeel van die relevansie van die betrokke metings. Daar is ' $n$ menigte van publikasies met net nog meer gegewens en akkurater gegewens, maar na verhouding ontbreek die betekenisvolle insig in die vraagstukke van die natuur.

* Die bioloë is byvoorbeeld swakker daaraan toe as hulle biologiese sisteme probeer reduseer na blote chemiese sisteme, want hulle ontwikkel as bioloë 'n „tacit knowledge" wat eie is aan die vakgebied en noodsaaklik vir sy vooruitgang.

* Statistiek is slegs betroubaar om 'n teorie as verkeerd te bewys maar nooit om dit as reg te bewys nie.

\section{Die implikasies}

Bogenoemde voorbeelde lewer onses insiens genoegsame getuienis dat neutraliteit nie, om dit ietwat paradoksaal te stel, die gangbare norm is in die natuurwetenskap nie. Die pertinente vraag is nou: Wat maak ons met hierdie gevolgtrekking? Om sonder meer oor te gaan na 'n pleidooi vir die handhawing van die Christelike norm, soos vervat in die Christelike wetenskapsideaal, sonder om die implikasies daarvan in oënskou te neem, sou onbedag wees. Sover die skrywer weet, was tot onlangs die voorstanders van Christelike wetenskapsbenadering die enigste pertinente deel van die akademiese en wetenskaplike wêre!d wat die neutraliteitsgedagte nie wou aanvaar nie. Dit was byna vanselfsprekend dat die bevraagtekening of teenkanting van 'n neutrale benadering 'n gelyktydige positiewe benadering van die Christelike wetenskapsideaal sou meebring. Die situasie het verander in die afgelope paar jaar. Harvey Brookes, Dekaan van Ingenieurswese en Toegepaste Wetenskappe by Harvard, skryf in 'n artikel ,Can science 
survive in the modern age' onder andere die volgende:

,A corollary view is that there is no such thing as objective knowledge, that all rational inquiry is inherently biased by the sociopolitical environment in which it is imbedded, not only in its selection of projects, but even in its conclusions, and that the claim of objectivity is a cover for defense of the status quo, especially, but not only, in the social and behavioral sciences. Granted that comp'ete objectivity is never possible, some turn this fact around and deduce that objectivity should not even be attempted, and that inquiry should be motivated by political commitment, specifically a radical commitment. This is, of course, an invitation to 'double-think', to the warping of conclusions to fit preconceived assumptions, but it has growing persuasiveness to many people, and seems to me completely incompatible with any true science.

Coupled with this attack on the possibility of objectivity, and advocacy of a radical nonobjectivity, is a deeper disillusionment with rationality in general and a flight toward antirational cults. Whereas radical nonobjectivity is the cult of what seems to be a 'lunatic fringe', antirationalism strikes an answering chord in a large number of peop'e, even particularly young, well-educated people. To me this is a more disturbing trend than radical nonobjectivity. Astrology, once the refuge of the ignorant and the illiterate, is now gaining favor among many in tellectuals, even young scientists, and is - God save the mark - being computerized. The national investment in astrology is between ten and twenty times that in astronomy. Eastern religions are enjoying a great vogue, and everywhere there is rising preoccupation with the emotional, the sensual, the affective aspects of human experience at the expense of the cognitive, systematic, and analytical aspects. Emotion-centered personality types are emerging as heroes to be emulated, again especially among the younger generation."

Hierdie skrywe van 'n geleerde uit een van Amerika se mees vooraanstaande universiteite dui aan dat die outonomie van die rede uit gans ' $n$ ander hoek bevraagteken word as dié 
van die Christelike wysbegeerte. Die Christen staan nou voor die volgende dilemma: Bepleit hy die erkenning van 'n normatiewe benadering tot die wetenskap, dan is dit seker die gewetensreg van elkeen om sy eie norm te kies en sodoende kan gevaarlik verkeerde vure aangeblaas word. Die oplossing is nie voor-die-hand-liggend nie. Een ding is seker, naamlik dat die eise van die Koningskap van Christus vir die persoonlike lewe van die wetenskaplike, ondubbelsinnig saam met die pleidooi vir 'n Christelike wetenskapsideaal gestel moet word sodat die wêreld duidelik kan verneem waarom dit eintlik gaan.

\section{Slotwoord oor die toekoms}

Op die terrein van die natuurwetenskappe was die daarstelling van 'n Christelike wetenskapsideaal onses insiens nog te polemies en verdedigend van aard. Daar is te veel vertoef by die evolusionisme en die eerste hoofstukke van die Bybel, terwyl die groot positiewe bydraes wat gemaak kan word, agterweë gebly het.

As die Christen-wetenskaplikes die inhoud van Psalm 8 verstaan en glo, sou dit nie aan die humaniste oorgelaat gewees het om die moderne probleme van die ekologie eerste raak te sien nie. Die besoedeling van die aarde se lug en waters en die kwistige verspilling van die planeet se natuurlike gawes moes hulle, wie die mens as wagter oor Gods handewerk sien, eerste bekommerd gemaak het oor die agterlosigheid van die wagter en die dure konsekwensies van sulke agterlosigheid.

Maar, daar is nuwe horisonne wat nog oneindig veel geleentheid en uitdaging bied. Tot dusver was die tegniese wetenskappe hoofsaaklik gemoeid met die studie van wat ons Moeder Natuur noem en die toepassing van die verworwe kennis. Die opkoms van die tegnologie en alles wat daarmee saamhang is egter besig om 'n nuwe wetenskapshorison te baar. Ons wil dit by wyse van illustrasie Moeder Tegnologie noem. Nuwe dissiplines is besig om te ontstaan. Hulle is nie net blote toepassings van die ou dissiplines soos fisika, chemie, ens, nie, maar hulle word vakgebiede in eie reg met hulle eie mode!le, wiskundige tegnieke, ens. In terme van die reeds bekende dissiplines is hulle dikwels multidissiplinêr van aard. 
Ons dink hier aan gebiede soos elektronika, rekenaarswetenskap, urbanologie, toekomskunde, ens. Daar is kleiner terreine wat nog geweldige groeipotensiaal het soos aerosolstudies en vibrasies van komplekse strukture. Sommige van hierdie studieterreine het 'n Macedoniese behoefte aan rigtinggewende norme. Neem bv 'n vak soos urbanologie, die studie van die groot stad. Dit bevat onder andere elemente van aardrykskunde, ekonomie, ingenieurswese, sosiologie, ens. Die mensdom neig om al meer en meer gekonsentreer te raak in groot stedelike komplekse met 'n legio geassosieerde probleme van uiteenlopende aard, maar steeds met die groot stad as die gemene deler. Dis onnodig om te beklemtoon dat vraagstukke soos vervoer, besoedeling, vryetydsbesteding, massifikasie, vereensaming, ens, veel navorsing, maar ook duidelike rigtinggewende bakens, vra. As hulle wie 'n Christelike lewensbeskouing huldig en uitleef nie hier daadwerklik kan help nie, sal die hulp van elders kom maar moontlik uit rigtings met konsekwensies wat ons nie ons kinders graag wil laat beleef nie. Die uitdaging en die moontlikhede vir die Christelike wetenskapsideaal het nou groter geword as ooit vantevore.

\section{Alberts}

Raad op Atoomkrag Pelindaba

\section{LITERATUUR}

1 H. van der Laan, A Christian Appreciation of Physical Science, Guardian Publishing Co 1966

2 L C Stecchini, The Inconstant Heavens; uit: The Velikovsky Affair. Sidgwick and Jackson 1966

3 The Encyclopaedia of Philosophy. Macmillan 1967

4 Michael Polanyi, 'n Oorsig deur H C Davis in: Scientific Research April 1969

5 W Heisenberg. Physics and Beyond. Harper and Row 1971

6 Harvey Brooks, Can Science Survive in the Modern Age? Science 1 Oktober 1971

7 B Paczynski, The Influence of Copernicus on Physics, Europhysics News Februarie 1973

8 A A L Challis, Bespreking van: Thinking about the Future. Endeavour Januarie 1974 